\title{
Identification of damages in the inlet air duct of a diesel engine based on exhaust gas temperature measurements
}

The temperature of the exhaust gas of a diesel piston engine, measured in the characteristic control sections of its thermo-flow system, can be a valuable source of diagnostic information about the technical condition of the elements limiting the working spaces thus separated, including the turbocharging system, but also its fuel supply system and replacement of the medium. In standard marine engine measurement systems equipped with an impulse turbocharging system, the exhaust gas temperature is measured at the outlet of individual cylinders and before and after the turbocharger turbine, using traditional thermocouples with high measurement inertia (time constant of tenths of a second and more). This means that for further diagnostic analyses, the average value of the periodically changing temperature of the exhaust stream leaving individual engine cylinders, the exhaust stream in the collective duct feeding the turbine and the exhaust stream in the exhaust duct of the turbine is used.

This article proposes a new approach to the issue of diagnostic informationiveness of the exhaust gas temperature of a diesel engine, extending its observations with the dynamics of changes in the duration of one working cycle. The aim of the tests carried out on the laboratory stand of Farymann Diesel engine type D10 was to determine the diagnostic relations between the loss of permeability of the inlet air channel filter baffle and selected standards of the quick-changing signal of the exhaust gas temperature. On the basis of the calculations carried out, the following dynamic features of the recorded signal were determined: maximum amplitude of instantaneous exhaust gas temperature values (peak-to-peak value), its rate of increase and decrease, and the specific enthalpy of exhaust gases within one engine work cycle.

Comparative analysis of numerical data characterizing the recorded quick-changing exhaust gas temperature courses clearly indicates obvious thermodynamic and energy consequences of partial loss of flow capacity of the air channel supplying the combustion chamber of the test engine.

A further development of the experimental test programme is foreseen in order to determine a diagnostic matrix to support the diagnostic inference about the technical condition of the diesel engine on the basis of measurements and analysis of the quick-changing exhaust gas temperature.

Key words: diesel engine, intake air channel, diagnostics tests

\section{Introduction}

Quick-changeable engine exhaust gas temperature allows the users to obtain diagnostic information on the technical condition of structural elements limiting the cylinder's working spaces, as well as inlet air and exhaust gas ducts $[1,2,12]$. In order to develop a diagnosis method based on this parameter, it is necessary to reconcile such requirements as: high accuracy of measurements, their costeffectiveness and technological efficiency. It is also important to minimize the influence of external factors on the accuracy of measurements. Therefore, it seems appropriate to use the method of measuring quick changeable temperatures with water-cooled thermocouple $[5,6,19]^{1}$.

\section{Conditions for laboratory testing}

Empirical tests were carried out on the laboratory test bed of a single-cylinder four-stroke diesel engine Farymann Diesel type D10 (Fig. 2). The research was aimed at recording in the selected control sections of the exhaust gas duct ${ }^{2}$ the temperatures of quick-changing exhaust gases. Then, on their basis, diagnostic parameters were determined for two

\footnotetext{
${ }^{1}$ If the thermocouple is not cooled, the recorded signal is disturbed, which results from the heating of the thermocouple from the surrounding gas, which is discussed in the publication [15].

${ }^{2}$ Variable: the temperature and pressure of the exhaust gas was recorded in the straight exhaust gas duct, at the same distance from the cylinder outlet valve, so that the signals were comparable and to prevent interference and reflection of pressure waves in the duct due to changes in the pipeline shape.
}

states: the reference one and the simulated loss of permeability of the inlet air channel filter baffle.

During the tests, the following control parameters and indicators of engine operation were recorded (described in Table 1):

- temperature of exhaust gases, by means of thermocouple type $\mathrm{K}$ cooled additionally with water jacket,

- exhaust gas pressure in the outlet duct,

- exhaust gas pressure in the combustion chamber,

- a signal of the upper dead position of the piston,

- load current of the generator (armature),

- voltage at the terminals of the generator armature,

- exhaust outlet valve opening signal.

A multifunctional measurement and recording module type DT-9805 from Data Translation was used to record quick-changing exhaust gas temperatures and pressures as well as the piston dead position signal,

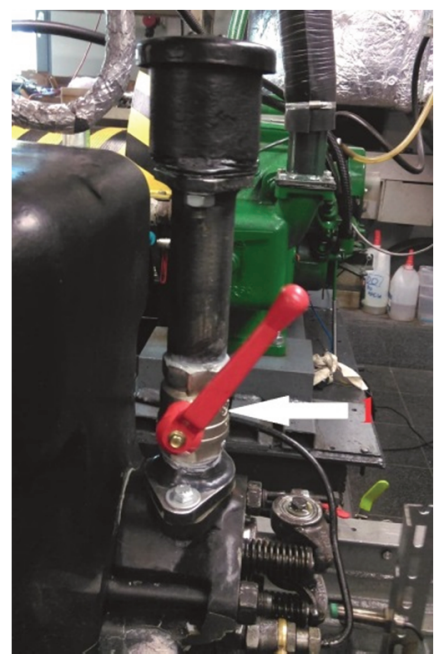

Fig. 1. A view of the inlet air duct supplying the engine: 1 - supply air control valve (degree of shutdown of the valve as during the laboratory 
while Matlab and Microsoft Excel software was used to record and mathematically process the recorded values of quick-changing exhaust gas temperatures. During the test, a constant crankshaft speed of the $1445 \mathrm{~min}^{-1}$ engine and a constant engine load were maintained. The sampling frequency was $7000 \mathrm{~Hz}$.

The test was carried out for two different technical states of the intake air channel: defined as state 1 (reference) and state 2, which caused changes in the active crosssectional area of the air flow through the valve mounted between the cylinder valve and the filter - Fig. 1. In this way, a reduction in the permeability of the filter baffle as a result of its contamination was simulated, which is quite often the state of inoperability of every internal combustion engine [3, 13].
The presented test results are the average of 90 consecutive measurements recorded under the same engine operating conditions, determined by the engine load, crankshaft rotational speed and environmental parameters. During the tests, distillation fuel ORLEN ECODIESEL was burnt in the engine.

In order to undergo mathematical treatment and statistical analysis of the obtained results of diagnostic tests of the engine, it is necessary to decide to compare the same data groups. The most reliable and comparable "portion" of data obtained during the recording of the observed quickvariable quantities was considered to be the results within one engine work cycle (from 0 to $720^{\circ} \mathrm{CSR}$ ). In order to allow for such an approach, it shall be assumed that the signal of the exhaust gas temperature variation is a periodic

Table 1. The parameters of the Farymann D10 single cylinder diesel engine recorded on the laboratory test stand

\begin{tabular}{|c|c|c|c|c|}
\hline Item & Parameter & Measuring device & unit & Measurement range \\
\hline 1. & Exhaust gas temperature $-\mathrm{T}_{\mathrm{sp} 1}$ & $\begin{array}{l}\text { Exposed junction type } \mathrm{K} \text { thermocouple } \\
\text { (junction diameter } 0.2 \mathrm{~mm} \text {, ceramic sheath) }\end{array}$ & ${ }^{\circ} \mathrm{C}$ & $0-1000$ \\
\hline 2. & Exhaust gas temperature $-\mathrm{T}_{\mathrm{sp} 2}$ & $\begin{array}{l}\text { Grounded type } \mathrm{K} \text { thermocouple with the } \\
\text { junction of external diameter of } 0.5 \mathrm{~mm} \text {, } \\
\text { made from inconell }\end{array}$ & ${ }^{\circ} \mathrm{C}$ & $0-1000$ \\
\hline 3. & $\begin{array}{l}\text { Exhaust gas pressure in the exhaust } \\
\text { channel }-\mathrm{p}_{\mathrm{sp}}\end{array}$ & Optical pressure sensor - Optrand C12296 & $\mathrm{V}$ & $\begin{array}{c}0-689475.73 \mathrm{~Pa}(0-100 \mathrm{psi}) \\
\text { sensitivity } 6.01 \cdot 10^{-8} \mathrm{~V} / \mathrm{Pa} \\
(41.43 \mathrm{mV} / \mathrm{psi})\end{array}$ \\
\hline 4. & $\begin{array}{l}\left.\text { Engine speed (angular position }{ }^{\circ} \mathrm{CA}\right)-\mathrm{n} \\
\text { Top dead center - TDC }\end{array}$ & $\begin{array}{l}\text { Induction engine speed sensor and TDC } \\
\text { sensor }\end{array}$ & $\min ^{-1}$ & $0-3000$ \\
\hline 5. & $\begin{array}{l}\text { Load Current of the generator (armature) - } \\
\mathrm{I}_{\mathrm{tw}}\end{array}$ & Electric current meter & A & $0-15$ \\
\hline 6. & Voltage at the armature terminals- $\mathrm{U}_{\mathrm{tw}}$ & Voltmeter & $\mathrm{V}$ & $0-250$ \\
\hline 7. & Exhaust valve opening signal & $\begin{array}{l}\text { Gap type opto-isolator with a comparator } \\
\text { LM393 }\end{array}$ & $\begin{array}{c}\mathrm{V} \\
\mathrm{mm}\end{array}$ & $\begin{array}{c}0-5 \\
10 \text { (gap) }\end{array}$ \\
\hline
\end{tabular}

a)

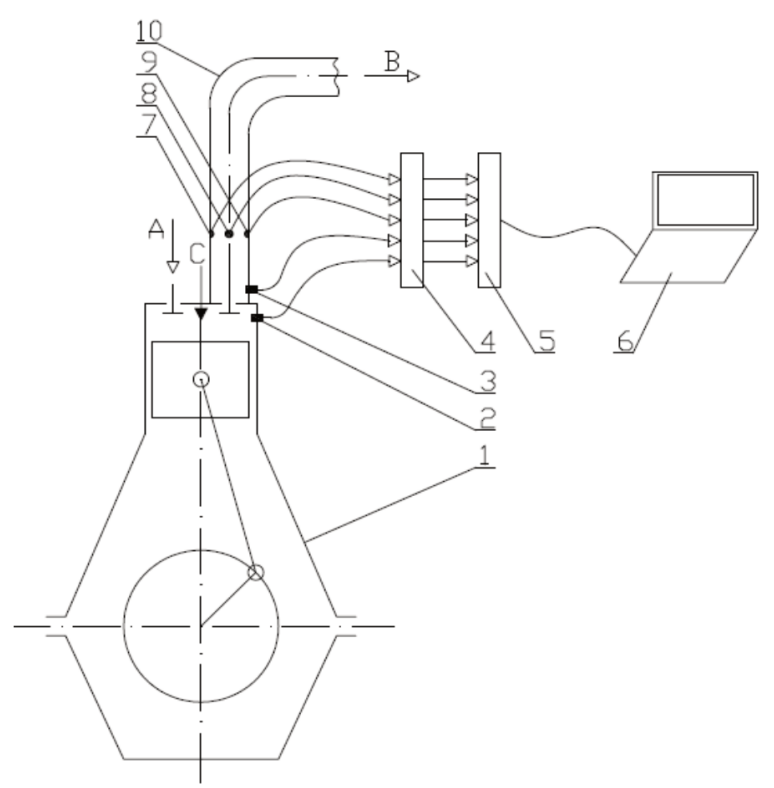

b)

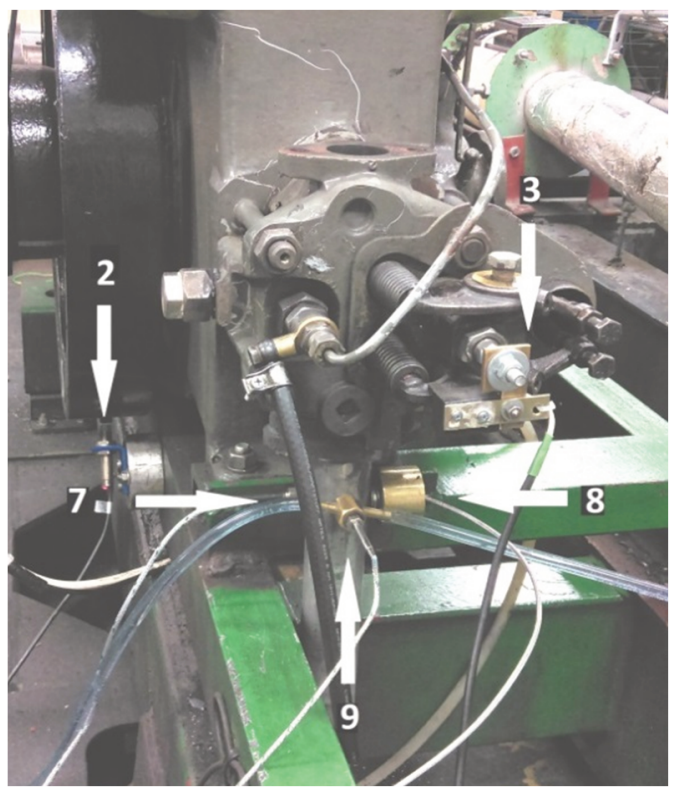

Fig. 2. a) Diagram of the laboratory test stand with the fitting spots of the sensors marked: 1 - Farymann D10 engine, 2 - engine speed and TDC sensor, 3 - exhaust valve opening sensor, 4 - A/C converter, 5 - recorder, 6 - analysis software, 7 - thermocouple in a ceramic sheath, 8 - pressure sensor, 9 water cooled thermocouple, 10 - exhaust gas channel, A - intake air, B - exhaust gas, C - fuel line; b) a view of the laboratory test stand with the fitting spots of the sensors of the recorded parameters marked: 2 - engine speed and TDC sensor, 7 - thermocouple in a ceramic sheath, 9 - water cooled thermocouple, 3 - exhaust valve opening sensor, 8 - pressure sensor 
signal. The time intervals analyzed in this study meet the conditions for their recognition as quasi-periodic, which is also acceptable $[7,8,10,11]$. The recorded signal of the engine exhaust gas temperature is periodically timedependent. Its values are repeated in constant intervals, lasting for a time called a period, that is:

$$
\mathrm{x}(\tau+\mathrm{T})=\mathrm{x}(\tau)
$$

The necessary condition is that the period (T) is any non-zero measurable number. This condition has been met in the case of analyzed signals of fast changing exhaust gas temperature $[15,17,18]$.

\section{Diagnostic parameters}

The results of the laboratory tests presented in this chapter refer to the temperature variation rates for a single diesel engine cycle. Four different measurement signal standards were analyzed, allowing to assess the technical condition of structural elements limiting the working spaces of the cylinder, as well as the air intake channel only on the basis of measurements and analysis of the quasi-periodic signal, which is the quasi-periodic temperature of the exhaust gas in the outlet duct $[9,14,16]$.

Dynamic exhaust gas temperature measurements in the selected control sections of the engine exhaust outlet channel make it possible to determine:

- the average peak to peak variable exhaust gas temperature (difference between maximum and minimum for the signal, within one engine cycle);

- specific enthalpy of subsequent temperature pulses of the exhaust gas leaving the cylinder;

- the rate (intensity) of increase and decrease in the value of the quick-changeable exhaust gas temperature for the single engine cycle.

On the basis of the course of quick-changeable temperature of the exhaust gases, the above mentioned standards of measurement signal values were determined, which may constitute adequate diagnostic parameters for the tested states of unfitness of the intake air channel. The results of their analysis are presented in the next chapters.

\subsection{An average peak-to-peak value}

\section{of the quick-changeable temperature}

The average peak-to-peak value of the quick-changeable exhaust gas temperature is determined as the difference between the maximum and minimum temperatures for each engine cycle (Fig. 3). The value of this diagnostic value was determined according to the relation:

$$
\Delta \mathrm{T}_{\mathrm{sr}}=\mathrm{t}_{\max }-\mathrm{t}_{\min }[\mathrm{K}]
$$

where: $\Delta \mathrm{T}_{\text {sr }}$ - average peak-to-peak value $[\mathrm{K}], \mathrm{t}_{\max }-$ maximum temperature of the exhaust gas within one engine cycle $\left[{ }^{\circ} \mathrm{C}\right], \mathrm{t}_{\min }-$ minimum temperature of the exhaust gas within one engine cycle $\left[{ }^{\circ} \mathrm{C}\right]$.

\subsection{A specific enthalpy of the exhaust gas}

The study of the temperature and pressure variability of exhaust gases leaving the cylinder of a diesel engine in the range of one work cycle gives the possibility of direct qualitative and quantitative assessment of the specific enthalpy of exhaust gases. The value of this parameter was determined by integrating the course of the quick-changeable temperature of exhaust gases within the limits specified by the values of the crankshaft rotation angle for one cycle, as well as by the known value of the specific heat of exhaust gases, depending on their average temperature:

$$
\mathrm{h}=\int_{0}^{720} \mathrm{c}_{\mathrm{p}\left(\mathrm{t}_{\mathrm{sp}}\right)} \cdot \mathrm{t}_{\mathrm{sp}} \mathrm{d} \alpha_{\mathrm{OWK}}\left[\frac{\mathrm{J}}{\mathrm{kg}}\right]
$$

where: $\mathrm{h}$-specific enthalpy of the exhaust gas $[\mathrm{J} / \mathrm{kg}], \mathrm{c}_{\mathrm{p}(\mathrm{tsp})}-$ average specific heat of the exhaust gas $[\mathrm{kJ} / \mathrm{kg} \cdot \mathrm{deg}], \mathrm{t}_{\mathrm{sp}}-$ the temperature of the exhaust gas recorded within one engine cycle $\left[{ }^{\circ} \mathrm{C}\right], \alpha_{\mathrm{OWK}}-$ the angle of the engine crankshaft revolution $\left[{ }^{\circ} \mathrm{CSR}\right]$.

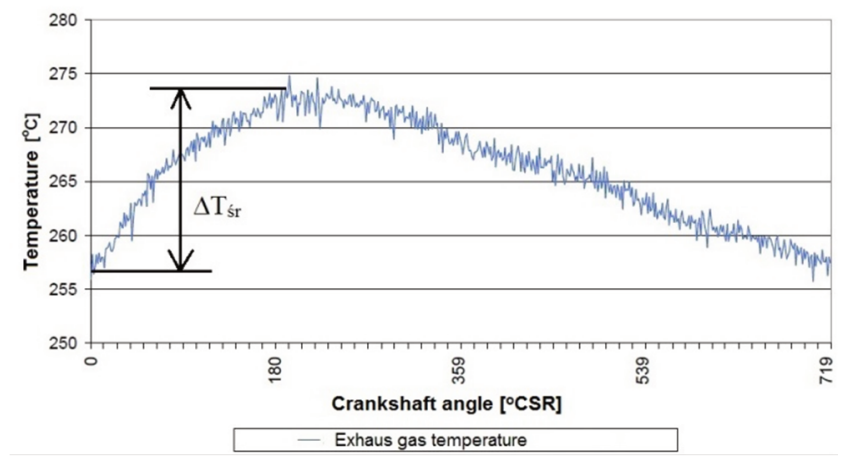

Fig. 3. The course of fluctuation of the quick-changing exhaust gas temperature for one engine cycle and the graphical interpretation of the peak-to-peak temperature value

The average specific heat of stoichiometric exhaust gases was determined on the basis of the chemical composition of exhaust gases recorded for each state of work of a diesel engine.

\subsection{A rate of the exhaust gas temperature's alterations}

Knowledge of the rate of increase and decrease in temperature of exhaust gases allows to determine the dynamics of this flow process. Figure 4 shows the graphical interpretation of the method of determining this diagnostic parameter for one engine cycle, based on a signal of a quickchanging exhaust gas temperature.

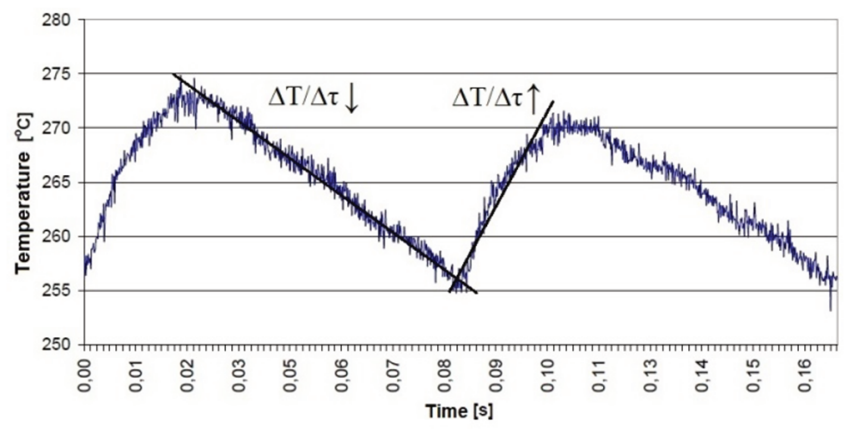

Fig. 4. The course of fluctuation of the quick-changing exhaust gas temperature for one engine cycle and the graphical interpretation of determining the rate of temperature increase and decrease

The rate of increase (decrease) of temperature of exhaust gases was determined according to the relation:

$$
\frac{\Delta \mathrm{T}}{\Delta \tau}=\frac{\mathrm{t}_{\max }-\mathrm{t}_{\min }}{\tau\left(\mathrm{t}_{\max }\right)-\tau\left(\mathrm{t}_{\min }\right)}
$$


where: $\Delta \mathrm{T} / \Delta \tau-$ rate of increase (decrease) of temperature of exhaust gas $[\mathrm{K} / \mathrm{s}], \mathrm{t}_{\max }-$ the maximum exhaust gas temperature within one engine cycle $\left[{ }^{\circ} \mathrm{C}\right], \mathrm{t}_{\min }$ - the minimum exhaust gas temperature within one engine cycle $\left[{ }^{\circ} \mathrm{C}\right], \tau\left(\mathrm{t}_{\max }\right)-$ the time during which the temperature of the exhaust gases within one engine cycle reaches its maximum value $[\mathrm{s}], \tau\left(\mathrm{t}_{\min }\right)-$ the time during which the temperature of the exhaust gases within one engine cycle reaches its minimum value [s].

\section{The results of measurements and calculations}

Diagnostic measures (parameters) described above have been determined for 2 experimental tests simulating various operating states of a diesel engine. Figures 5 and 6 show the time courses of quick-changeable exhaust gas temperature obtained from ten consecutive engine operation cycles for the two considered technical states of the intake air channel. The presented signals of quick changing temperature were subjected to mathematical treatment in order to remove interference from the measuring network. The measured exhaust gas temperature values achieved during the laboratory engine test were filtered using the method of least squares in the Microsoft Excel software environment.

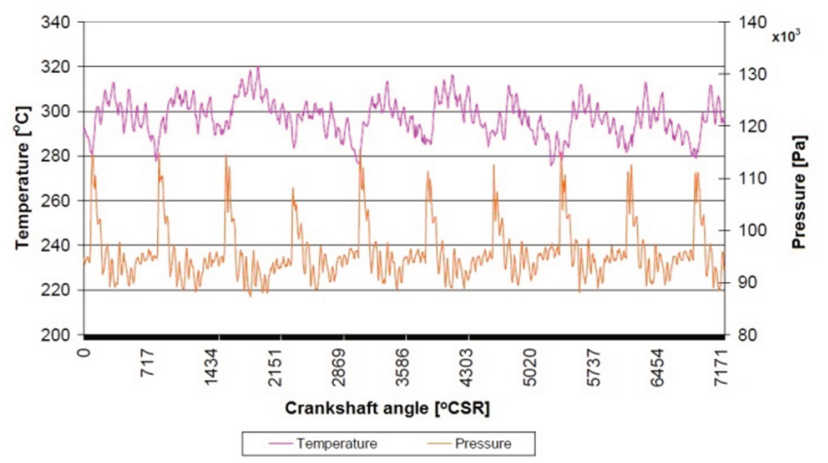

Fig. 5. Time courses of the quick changeable temperature and exhaust gas pressure obtained from ten consecutive engine cycles for state 1 - with the valve regulating the air supply to the engine cylinder fully open

Table 2 presents a summary of the diagnostic parameters determined during the testing of the Farymann engine type D10 in the two considered technical conditions of the intake air channel. The data presented in the table are average values, given for a group of 90 engine operating cycles recorded during the measurements. They refer to a single engine cycle for comparative analysis of defined measurement standards of recorded signals. Figures 7 and 8 show the achieved values of diagnostic parameters in a graphical form for a more readable interpretation of numerical data.

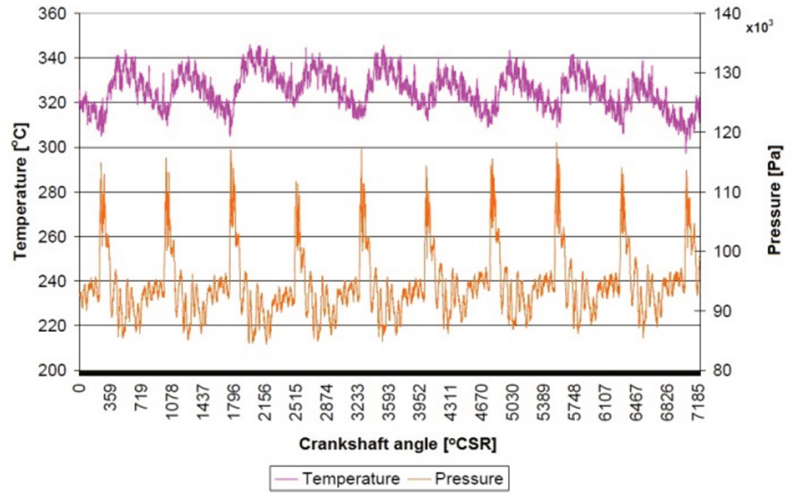

Fig. 6. Time courses of the quick-changeable temperature and exhaust gas pressure obtained from ten consecutive engine cycles for state 2 with the partially closed valve regulating the air supply to the engine cylinder (as in Figure 1)

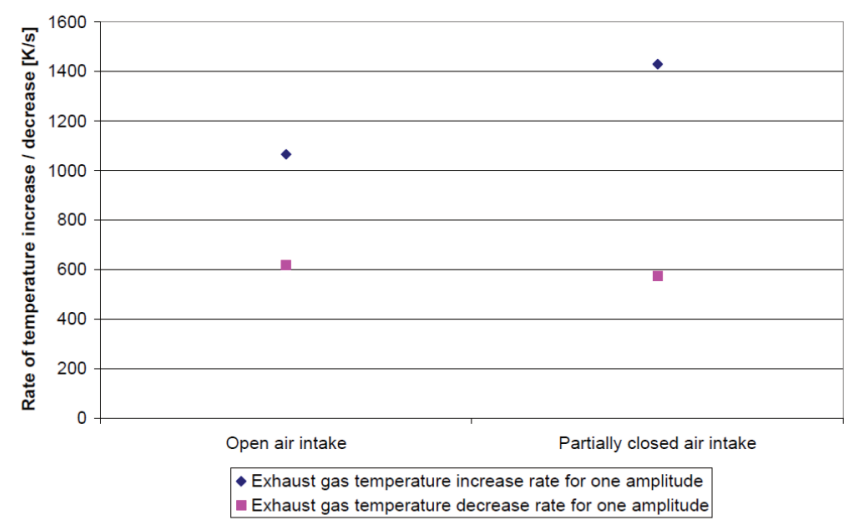

Fig. 7. Values of diagnostic parameters, such as the average rate of increase and decrease of exhaust gas temperature within one engine operating cycle, depending on the technical condition of the intake air channel

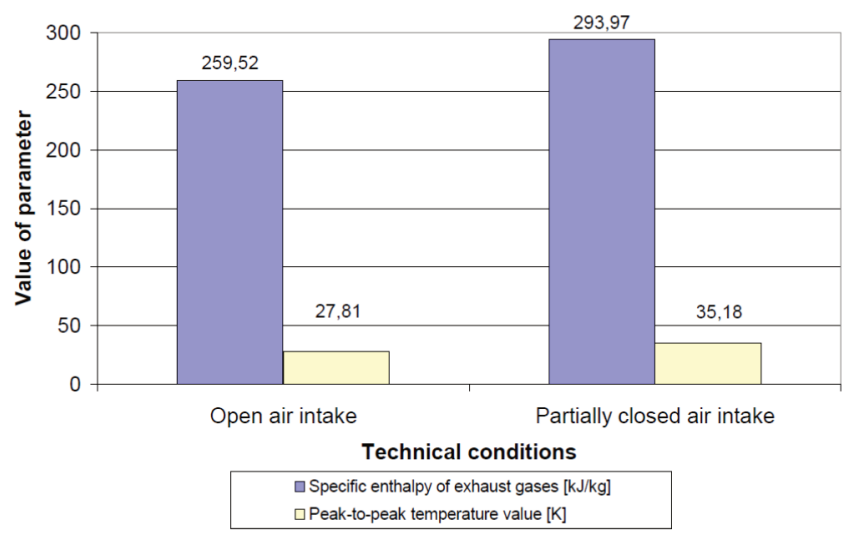

Fig. 8. Values of diagnostic parameters such as specific enthalpy and peakto-peak exhaust gas temperature within one engine cycle, depending on the technical condition of the intake air channel

Table 2. Summary of determined values of diagnostic parameters with their standard deviations

\begin{tabular}{|c|c|c|c|c|c|}
\hline \multicolumn{2}{|c|}{ Diagnostic parameter } & \multirow{2}{*}{$\begin{array}{c}\Delta \mathrm{T}_{\mathrm{s} r}[\mathrm{~K}] \\
\begin{array}{c}\text { Peak-to-peak temperature } \\
\text { value }[\mathrm{K}]\end{array}\end{array}$} & \multirow{2}{*}{$\begin{array}{c}\mathrm{h}[\mathrm{kJ} / \mathrm{kg}] \\
\text { Specific enthalpy of } \\
\text { exhaust gas }[\mathrm{kJ} / \mathrm{kg}]\end{array}$} & \multirow{2}{*}{$\begin{array}{c}\Delta \mathrm{T} / \Delta \tau \uparrow[\mathrm{K} / \mathrm{s}] \\
\text { Exhaust gas temperature } \\
\text { increase rate for one ampli- } \\
\text { tude }[\mathrm{K} / \mathrm{s}]\end{array}$} & \multirow{2}{*}{$\begin{array}{c}\Delta \mathrm{T} / \Delta \tau \downarrow[\mathrm{K} / \mathrm{s}] \\
\text { Exhaust gas temperature decrease } \\
\text { rate for one amplitude }[\mathrm{K} / \mathrm{s}]\end{array}$} \\
\hline $\begin{array}{l}\text { Technical } \\
\text { condition }\end{array}$ & Operating condition & & & & \\
\hline \multirow{2}{*}{1} & Average value & 27.81 & 259.52 & 1064.71 & 615.80 \\
\hline & Standard deviation & 2.20 & 5.33 & 226.91 & 110.08 \\
\hline \multirow{2}{*}{2} & Average value & 35.18 & 293.97 & 1428.78 & 573.72 \\
\hline & Standard deviation & 2.73 & 4.03 & 272.17 & 74.33 \\
\hline
\end{tabular}




\section{Comparison of the calculation results}

The peak-to-peak value of the exhaust gas temperature was significantly higher for a partially closed air intake duct than in the reference state (differences exceeding the standard deviation). The diagnostic parameter that is averaged over one engine work cycle of the exhaust gases specific enthalpy showed a much higher value (apart from the standard deviation) for a test with a partially closed air intake relative to the reference state. For the diagnostic parameter, i.e. the exhaust gas temperature increase rate within one engine cycle, large standard deviations of this parameter are visible (even $20 \%$ of the average value). There is also a significant discrepancy in the results obtained for each technical condition. Significantly higher value compared to the reference state was observed for a state with a partially closed air intake. The exhaust gas temperature increase rate also informs about the dynamic properties of the thermocouple used during laboratory tests [15]. The rate of exhaust gas temperature's decrease is also characterized by significant standard deviations (up to $17 \%$ of the average value), as is the case with the rate of exhaust gas temperature increase. However, there is less discrepancy between the achieved average values of this diagnostic parameter. A value significantly lower than the reference state was observed for a study with a partially closed air intake. It is also visible that the rate of decrease of quick changing exhaust gas temperature is about 2 times lower than the rate of increase of this parameter. This is due to the slower cooling of the thermocouple than heating.

Diagnostic parameters determined on the basis of measurements of quick-changeable exhaust gas temperature, such as specific enthalpy, peak-to-peak value and temperature increase rate, react similarly to changes in the structure of the engine intake air channel during the laboratory engine tests.

In the next step of the laboratory tests it is planned to determine Sankey's stream charts. They will be used as an energy background for studies of the influence of selected diesel engine defects on the quick-changing signal of exhaust gas temperature $[4,20]$.

\section{Bibliography}

[1] BROWN, C., KEE, R.J., IRWIN, G.W. et al. Identification applied to dual sensor transient temperature measurement. UKACC Int. Control Conference. Manchester 2008.

[2] JAREMKIEWICZ, M. Odwrotne zagadnienia wymiany ciepła, występujące w pomiarach nieustalonej temperatury płynów. Rozprawa doktorska. Wydawnictwo Politechniki Krakowskiej. Kraków 2011.

[3] JAREMKIEWICZ, M., TALER, J. Inverse determination of transient fluid temperature in pipelines. Journal of Power Technologies. 2016, 96(6), 385-389.

[4] KORCZEWSKI, Z. Badania efektywności energetycznej nowo produkowanych paliw żeglugowych z zastosowaniem silnika diesla. Journal of Polish CIMEEAC. 13, 1(5), 53-64.

[5] KORCZEWSKI, Z. Exhaust gas temperature measurements in diagnostics of turbocharged marine internal combustion engines. Part I. Standard Measurements. Polish Maritime Research. 2015, 22/1(85), 47-54.

[6] KORCZEWSKI, Z. Exhaust gas temperature measurements in diagnostics of turbocharged marine internal combustion engines. Part II. Dynamic Measurements. Polish Maritime Research. 23/1(89), 68-76.

[7] KORCZEWSKI, Z. Diagnostyka eksploatacyjna okrętowych silników spalinowych - tłokowych i turbinowych. Wybrane zagadnienia. Wyd. Politechniki Gdańskiej. Gdańsk 2017.

[8] KORCZEWSKI, Z. The method of energy-efficiency investigations of the newly produced marine fuels through the application of a diesel engine. Materiały Konferencji MAPE, Explo-Ship 2018. Zawiercie.

[9] KORCZEWSKI, Z., PUZDROWSKA, P. Analytical method of determining dynamic properties of thermocouples used in measurements of quick - changing temperatures of exhaust gases in marine diesel engines. Combustion Engines. 2015, 162(3), 300-306.

[10] KORCZEWSKI, Z., ZACHAREWICZ, M. Alternative diagnostic method applied on marine diesel engines having limited monitoring susceptibility. Transactions of the Institute of Measurement and Control. 2012, 34(8), 937-946.

[11] KORCZEWSKI, Z., ZACHAREWICZ, M. Diagnostyka symulacyjna układu turbodoładowania okrętowego tłokowego silnika spalinowego. Zeszyty Naukowe Akademii Marynarki Wojennej. 2007, 2(169).
[12] KOWALSKI, J., Laboratory study on influence of air duct throttling on exhaust gas composition in marine four-stroke diesel engine, Journal of KONES. 2015, 19(1), 191-198.

[13] KOWALSKI, J. The emission and combustion characteristics of marine diesel engine with extreme throttled of air or exhaust ducts. New Trends in Production Engineering. 2018, 1(1), 427-433.

[14] MARSZAŁKOWSKI, K., PUZDROWSKA, P. A laboratory stand for the analysis of dynamic properties of thermocouples. Journal of Polish CIMEEAC. 2015, 10(1), 111-120.

[15] OLCZYK, A. Koncepcja pomiaru szybkozmiennej temperatury gazu z uwzględnieniem dynamicznej składowej temperatury. Pomiary Automatyka Kontrola. 2007, 53/9, 576-579.

[16] PUZDROWSKA, P. Determining the time constant using two methods and defining the thermocouple response to sine excitation of gas temperature. Journal of Polish CIMEEAC. 2016, 11(1), 157-167.

[17] PUZDROWSKA, P. Metoda wyznaczania stałej czasowej termopary na podstawie pomiaru szybkozmiennej temperatury spalin wylotowych silnika o ZS. Zeszyty Naukowe Akademii Morskiej w Gdyni. 2018, 108, 115-133.

[18] PUZDROWSKA, P. Signal filtering method of the quickvarying diesel exhaust gas temperature. Combustion Engines. 2018, 175(4), 48-52.

[19] RUDNICKI, J., PUZDROWSKA, P., MARSZAŁKOWSKI, K. Osłona termopary chłodzona wodą jako narzędzie zapobiegające zakłóceniom zewnętrznym podczas pomiarów temperatur szybkozmiennych spalin w kanale wylotowym silnika okrętowego. Journal of Polish CIMAC. 2017, 12(1), 97-104.

[20] ZACHAREWICZ, M. Metoda diagnozowania przestrzeni roboczych silnika okrętowego na podstawie parametrów procesów gazodynamicznych w kanale zasilającym turbosprężarkę. Rozprawa doktorska. AMW, Gdynia 2009.

Patrycja Puzdrowska, MEng. - Faculty of Ocean Engineering \& Ship Technology, Gdansk University of Technology.

e-mail: patpuzdr@pg.edu.pl 